\title{
Jamaluddin al-Afghani dan Karir Politiknya
}

\author{
Arbi Mulya Sirait ${ }^{1}$ \\ ${ }^{1}$ Institut Agama Islam Negeri (IAIN) Tulungagung \\ larbimulya77@email.com
}

\begin{abstract}
In its history, Islam has had a phase where it has progressed in various ways, one of which is in the political realm. This is marked by the number of areas that were successfully conquered by Islam so that its teachings also developed very rapidly. However, in history, Islam has also experienced a period of decline where there have been many divisions among internal Muslims as well as due to external influences, and some of the causes are the advancement of Western civilization so that it affects the existence of the world of Islamic politics as well. The data obtained from this paper comes from various references in the form of books, journals, and other writings. Then the data is reviewed to produce a conclusion. In this paper, we will discuss how Jamaluddin al-Afghani's efforts in arousing the spirit of unity of the Muslim community in order to escape from western influences and shadows, as well as his efforts to improve the internal conditions of Muslims, both social, political and religious. Jamaluddinal-Afghani the first reformer in Islam who brought salafiyah under the banner of Pan Islamism, with the principle that Muslims wherever he is is the Unity of Brotherhood or a unity of brotherhood that must be fostered continuously. Jamaluddin said that the only most revolutionary way to liberate the fate of Muslims from colonialism, imperialism and materialism was politics imbued with religion. Jamaluddin, as an islamic reformer, tried hard to improve Islam from within by completely attacking superstition, khurafat and bid'ah.
\end{abstract}

\section{Key Word: Jamaluddin al-Afghani, Pan-Islamism, Political Islam}

\begin{abstract}
Abstrak
Dalam sejarahnya, Islam mempunyai fase di mana ia mengalami kemajuan di berbagai hal, salah satunya dalam ranah politik. Hal itu ditandai dengan banyaknya daerah-daerah yang berhasil ditaklukkan Islam sehingga ajarannya pun ikut berkembang sangat pesat. Akan tetapi, dalam sejarah, Islam juga pernah mengalami masa kemunduran di mana terjadi banyak perpecahan di kalangan internal muslim maupun akibat dari pengaruh luar, dan beberapa penyebabnya adalah majunya peradaban Barat sehingga memengaruhi eksistensi dunia perpolitikan Islam juga. Data yang didapat dari tulisan ini berasal dari berbagai referensi baik berupa buku, jurnal, dan tulisan-tulisan lainnya. Kemudian data tersebut ditelaah sehingga menghasilkan sebuah kesimpulan. Dalam tulisan ini akan membahas tentang bagaimana upaya Jamaluddin al-Afghani dalam membangkitkan semangat kesatuan umat muslim agar bisa lepas dari pengaruh dan bayang-bayang Barat, serta upayanya dalam membenahi kondisi internal umat muslim baik sosial, politik, maupun keagamaan. Jamaluddinal-Afghani reformer pertama dalam Islam yang membawakan faham salafiyah di bawah naungan panji Pan Islamisme, dengan
\end{abstract}


prinsip bahwa umat Islam di manapun ia berada adalah merupakan The Unity of Brotherhood atau satu kesatuan persaudaraan yang harus dibina terus. Jamaluddin mengatakan bahwa, satu-satunya yang paling revolusioner untuk membebaskan nasib umat Islam dari kolonialisme, imperialisme dan materialisme hanyalah dengan politik yang dijiwai dengan agama. Jamaluddin sebagai reformer Islam berusaha keras memperbaiki Islam dari dalam dengan menyerang habis-habisan faham takhayul, khurafat dan bid'ah.

Kata Kunci: Jamaluddin al-Afghani, Pan-Islamisme, Politik Islam

\section{Pendahuluan}

Dalam dunia Islam, agama dan politik ibarat dua sisi mata uang yang sangat terkait. Banyak sekali doktrin-doktrin agama yang terkait dan dipengaruhi oleh aspek politik. Demikian juga Islam memberikan nuansanuansa baru terhadap politik, sehingga dapat menjadikan disiplin ini berbeda dengan sistem politik dalam tradisi keilmu yang lain.

Jamaluddin al-Afghani merupakan sosok reformis yang gencar menyerukan gerakan perlawanan terhadap penjajahan yang dilakukan oleh Barat terhadap dunia Islam. Salah satu usaha untuk melakukan perlawanan tersebut yaitu dengan mempersatukan umat muslim yang terpecahbelah pada waktu itu. Oleh sebab itu muncullah istilan Pan Islamisme, yaitu usaha untuk mempersatukan dunia Islam, meluruskan pemahaman-pemahaman yang selama ini melenceng dari syari'at Islam, memperbaiki tatanan sosial, dan tentunya memperbaiki kondisi perpolitikan Islam agar terbebas dari pengaruh atau campur tangan asing (Barat).

Pemikiran dalam ranah politik Islam merupakan bagian penting dalam perjalanan sejarah intelektual manusia secara umum, dan perjalanan sejarah intelektual muslim pada khususnya. Tradisi intelektual ini terpisah dari tradisi asing (Barat). Dalam membahas politik Islam, Jamaluddin alAfghani merupakan sosok yang menarik untuk kita telaah pemikirannya.

Gagasan nasionalisme dan negarabangsa dengan gagasan negara kekhalifahan mempunyai perbedaan yang sangat mencolok. Gagasan negara-bangsa berkembang dari abad pertengahan di kalangan bangsa Eropa Barat. Gagasan negara-bangsa bersifat lintas batas agama dalam ranah kekuasaan dan bersifat lokal secara kewilayahan. Hal tersebut sangat berbeda bagi kaum muslim karena gagasan kekhalifahan yang mana ranah kekuasaannya bersifat tertutup (terbatas bagi pemeluk Islam).

Dari uraian di atas pada akhirnya menimbulkan perhatian yang lebih komprehensif terhadap fenomena perkembangan pemikiran politik di kalangan umat muslim dewasa ini. Dari segi politik, cita-cita pembentukan negara Islam merupakan usaha untuk mencari sebuah 
formulasi bentuk negara yang asal muasalnya bisa ditelusuri dari ketegangan antara pemikiran ihwal negara kekhalifahan dan pemikiran tentang negara bangsa.

\section{Negara kekhalifahan} memang sendiri. ${ }^{1}$

memudar dalam realitas sejarah, akan tetapi tidak mudah bagi pemikir muslim pada waktu itu untuk menghilangkan begitu saja konsep politik yang mempunyai bukti empirik selama berabad-abad dan sudah dipandang sebagai kontinuitas kesatuan politik dan kewilayahan Islam. Sebaliknya, realitas kemunculan nasionalisme sebagai basis negara bangsa ternyata juga tidak mudah mereka terima begitu saja, tentunya dengan berbagai macam alasan. Oleh sebab itu muncullah upaya menemukan gagasan politik baru yang relatif berbeda dari gagasan-gagasan negara kekhalifahan ataupun gagasan nasionalisme.

Contoh yang cukup representatif untuk pencarian gagasan alternatif tersebut bisa kita lihat dari apa yang sudah dilakukan atau dicetuskan oleh Jamaluddin al-Afghani yaitu dengan gerakan Pan Islamisme nya. Gerakan ini mempunyai tujuan yaitu untuk menyatukan seluruh umat Islam di dunia berdasarkan persamaan dan solidaritas akidah dalam rangka membangun Persatuan Islam. Gerakan ini juga mensyaratkan sebuah asosiasi politik yang menghimpun seluruh pemimpin negeri-negeri Islam dengan kedudukan sederajat. Untuk mensukseskan keinginan yang diinginkan oleh Jamaluddin tersebut, beliau selalu menyerukan perlawanan bukan hanya terhadap penjajahan barat akan tetapi juga terhadap sistem pemerintahan despotik di negeri-negeri Islam

Mengkaji pemikiran Jamaluddin AlAfghani sangatlah menarik karena pemikiran-pemikirannya mempunyai banyak pengaruh dalam dunia politik sosial maupun keagamaan di berbagai negara. Maka dari, itu dalam tulisan ini membahas tentang sosok Jamaluddin Al-Afghani beserta pemikiranpemikirannya terutama dalam hal perpolitikan Islam, baik tantangan maupun peluangnya. Dari tulisan ini diharapkan mampu memberikan kontribusi pengetahuan tentang sejarah politik Islam beserta implementasinya dalam perkembangan dunia Islam.

\section{Metode Penelitian}

Kajian ini merupakan penelitian kepustakaan yang terkategori sebagai bagian dari riset kualitatif. Sumber datanya adalah berbagai referensi tentang Jamaluddin alAfghani yang kemudian dianalisis dengan metode analisis isi

\section{Hasil Penelitian dan Pembahasan}

\section{Biografi Ringkas Jamaluddin Al-Afghani}

$$
\text { Jamaluddin al-Afghani adalah }
$$
seorang pemikir pembaru yang mana 
gerakannya lebih banyak berkecimpung di terpecah belah karena penjajah Barat. bidang politik, moral, intelektual, dan sosial. Beliaulah orang Islam pertama yang Di samping mengajak umat muslim untuk menyadari akan bahaya dominasi Barat dan kembali kepada ajaran Islam asli (al-Qur'an mengabdikan dirinya untuk memberikan dan Sunnah), ia juga membangkitkan peringatan ke dunia Islam akan hal tersebut. semangat kaum muslim untuk melawan Nama asli Jamaluddin Al-Afghani penjajah dari kekuasaan yang absolut serta adalah Muhammad bin Safdar, lahir di mengajak umat muslim agar mempelajari Kabul, Afganistan pada tahun 1254 H-1314 sains dan teknologi Barat tanpa terbaratkan. ${ }^{2}$

H/1839 M-1897M. Keluarganya adalah

Hal tersebut sebagaimana yang keturunan orang ternama dan sangat dijelaskan Bernard Lewis ${ }^{3}$, ia menjelaskan bahwa pada masa dominasi kekuasaan berpengaruh, yaitu al-Tirmizi keturunan imperialisme dan kolonialisme Barat, Husen bin $\mathrm{Ali}^{4}{ }^{4}$ Pada umur 18 tahun dia Jamaluddin al-Afghani merupakan orang pertama yang mengambil sikap politik, yang di kemudian hari mengilhami munculnya gerakan-gerakan kemerdekaan melawan imperialisme Barat. Al-Afghani lebih dikenal sebagai pencetus ide-ide dan gerakan antikolonialisme Barat di kalangan umat Islam pada zaman modern.

Jamaluddin al-Afghani juga dikenal sebagai reformis pertama-pasca kemunduran dunia Islam-yang banyak membahas tentang "tugas kemasyarakatan Nabi” karena ia menyadari bahwa telah terjadi kemunduran spiritual dan material di dunia Islam. Perjuangan yang ia lakukan bertujuan untuk membangun sistem politik berdasarkan persaudaraan Islam yang telah mempelajari cabang-cabang ilmu pengetahuan Islam dan filsafat serta ilmu pasti. Ia pernah tinggal di India untuk beberapa tahun kemudian ia melaksanakan ibadah haji ke Makkah pada tahun 1273 H./1857M. Sekembalinya dari melaksanakan ibadah haji ia langsung kembali ke Afganistan dan menjabat sebagai pembantu Amir Dust Muhammad Khan, untuk mengobarkan kampanyenya di bidang politik. Pada tahun 1285 dia kembali melaksanakan ibadah haji untuk kedua kalinya, kemudian pergi ke Kairo untuk mengadakan kontak dengan al-Azhar. Di sana ia mengadakan perkuliahan privat, dan tahun $1287 \mathrm{H}$ ia mengunjungi Konstantinopel sebuah kota yang begitu memberi sambutan yang sangat hangat terhadapnya.

Kondisi Konstantinopel yang demikian bagus ternyata membawa angin

4 HAR Gibb and J.H Kramers, Shorter Encyclipedia of Islam (Nederland: Shorter Encyclipedia of Islam, 1961), h. 85. 
segar terhadap reputasinya. Dengan kekayaan ilmu pengetahuan dan keuletannya, pemerintah mengambil keputusan untuk menjadikannya sebagai Guru Besar di Masjid Aya Sofia dan Masjid Ahmadiyah bagi para mahasiswa di samping sebagai tenaga pengajar di Universitas Daar-al Funun.

Ada perbedaan pendapat terkait asal usul tempat kelahiran Jamaluddin ini. Menurut pengakuannya ia dilahirkan di As'adabad dekat kanar wilayah kabul Afghanistan. Tetapi ada versi lain yang mengatakan ia dilahirkan di As'adabad dekat hamadan wilayah Persia.

Ali Rahnema dalam tulisan Noorthaibah $^{5}$ menyatakan bahwa tidak ditemukan sumber primer yang mendukung tempat lahirnya Al-Afghani, akan tetapi banyak sumber yang menjelaskan bahwa ia dilahirkan dan mendapat pendidikan Syi'ah di Iran. Pernyataan tersebut didukung dengan banyaknya tulisan tentang Al-Afghani yang memperlihatkan bahwa dirinya mendapat pendidikan di Iran .

Terlepas dari perbedaan pendapat terkaiat asal usul beliau, yang jelas AlAfghani mempunyai peranan yang sangat penting dalam dunia politik Islam. Ia telah banyak dikenal oleh masyarakat muslim di dunia dan sangat berpengaruh terhadap dunia Islam, terlebih dalam kancah politik Islamnya.

5 Noorthaibah, "Pemikiran Pembaharuan Jamaluddin Alafghani: Studi Pemikiran Kalam Tentang Takdir," Fenomena Vol. 7 (2015), h. 261. Jurnal Intelektual: Jurnal Pendidikan dan Studi Keislaman Volume 10, Nomor 2, Agustus 2020

\section{Ide dan Perjuangannya}

Negara-negara Barat sangat dikenal sebagai negara maju khususnya di bidang ilmu pengetahuan, teknologi dan ekonomi. Namun ia juga cukup dikenal sebagai negara kolonialis, imperialis, komunis dan materialis. Bagi dunia Barat, dunia Timur merupakan dunia pujaan yang sering dijadikan sebagai sasarannya, terutama pada daerah-daerah jajahan mereka, mereka mengadakan tekanan-tekanan baik di bidang fisik mupun psikis tanpa menghiraukan hidup dan nasib rakyat. Tekanan-tekanan politik, ekonomi serta psikologis yang dilakukan oleh penjajah cukup menjadikan rakyat semakin menderita, yang sering menjadikan kesabaran dari rakyat menjadi hilang. Sudah barang tentu mereka menuntut kehormatan, harga diri sebagai manusia.

Untuk mengembalikan status mereka sebagai manusia yang ditekan dan ditindas, mereka harus berjuang untuk mengadakan perombakan dan pembaharuan dalam berbagai bidang. Dalam suasana yang demikian, muncul tokoh pembaharu dan perintis yang begitu gigih mempertahankan ide-idenya tanpa mengenal lelah serta tidak mengaharap imbalan, dan semata ikhlas dalam perjuangan, itulah Jamaluddin alAfghani.

Bila diperhatikan secara seksama pergerakan pembaharuan umum yang pertama dalam abad ke 19 ternyata punya dua karakter, yaitu dalam aspek agama dan 
politik. Dalam bidang agama, pergerakan ini fokus dan menuntut pembersihan kepercayaan (akidah) dan perilaku keagamaan, kemudian berikutnya tingkat kecerdasan dan perluasan modernisasi pendidikan. Kemudian dalam bidang politik, pergerakan yang dilaksanakan bertujuan menghilangkan berbagai faktor yang bisa memecah belah kaum muslimin dan bagiamana menyatukan mereka untuk mempertahankan iman. ${ }^{6}$ Dengan demikian bentrokan dengan dunia Barat, secara langsung maupun tidak akhirnya dapat mendatangkan kebangkitan dunia yang berbahasa Arab setelah mengalami kebekuan berpikir selama berabad-abad. ${ }^{7}$

Di tengah-tengah kondisi yang berkobar inilah Jamaluddin al-Afghani menampakkan kepiawaian pemikirannya serta kemampuannya untuk membela yang tertindas dari perangkap kaum penjajah. Langkah-langkah politik yang diambilnya sangat bersifat revolusioner, tidak kenal kompromi sehingga ia dianggap sebagai seorang juru bicara yang berbahaya oleh lawan-lawannya, terutama bangsa Inggris yang sangat menakutinya, sehingga terus menerus berusaha membinasakannya. Jika Muhammad Abdul Wahab terkenal sebagai seorang pembaharu di bidang akidah dan

6 HAR Gibb, Muhammedenism, Terj. Abu Salama. Islam Dalam Lintasan Sejarah (Jakarta: Bhrata, 1961), h. 144. ${ }^{7}$ Zaki Hazem, The Ideas of Arab Nationalism, Terj. Mertodipuro Gagasan Nasionalisme Arab (Jakarta: Bhrta, 1969), h. 32.
Mudat Pasha sebagai reformer Islam dalam bidang politik pemerintahan, maka Jamaluddin al-Afghani terkenal sebagai pembangun Islam yang anti kolonialisme dan sebagai pembaharu di bidang intelektual yang berjiwa pejuang. Ketika menghadapi kekuatan kolonial, dialah orang yang mengambil langkah-langkah politik yang dihubungkan dengan agama.

Jamaluddin al-Afghani berpendapat bahwa manusia akan dapat mengalami kebahagiaan dan kesejahteraan apabila ia memiliki syarat-syarat seperti berikut:

1. Akal rakyat harus bisa dibersihkan dari kepercayaan-kepercayaan yang bersifat takhayul dan kepercayaan orang-orang bodoh. Tuhan itu Maha Esa meminta supaya akal manusia dibersihkan dari segala bid'ah dan kembali kepada ajaran tauhid yang murni.

2. Orang harus merasa dirinya dapat mencapai tingkatan kemuliaan yang tinggi, dan harus punya keinginan untuk itu. Hanya satu hal yang tak bisa diperoleh manusia, yaitu pangkat kenabian, sebab Tuhan hanya menganugerahkannya pada siapa yang dikehendaki-Nya. Jika semua orang punya perasaan seperi itu, pastilah orang berlombalomba untuk meningkatkan budi yang tinggi.

3. Rukun iman suatu umat haruslah dijadikan pelajaran yang pertama-tama baginya dan disertai dengan dalil-dalil supaya ia tidak terkesan sebagai ikut-kutan saja. Islam sangat menghormati akal manusia dan seseorang 
menerima keterangan agama dengan

keterangan yang memuaskan, bukan sekedar pengakuan.

4. Dalam setiap umat harus ada sekelompok orang yang selalu memberi pelajaran kepada masyarakat banyak, dan mendidik ke arah budi yang terpuji (al-Imran ayat 104).

Ada beberapa hal yang mengilhami Jamaluddin al-Afghani untuk memulai gerakan reformasinya (Pan Islamisme), yakni negara-negara Islam yang semakin melemah, dominasi negara Eropa atas ekonomi dan politik, serta penyebaran paham materialisme dan ateisme.

Pan Islamisme dalam pengertian yang luas adalah rasa solidaritas antara seluruh Muslim. $^{8}$ Rasa persaudaran ini adalah sebagai satu aspek sistem Islam yang sangat mendasar. Seorang muslim adalah saudara bagi muslim lainnya. Tema Pan Islamisme yang dicanangkan oleh al-Afghani, adalah merupakan tanggapan positif terhadap akibat bentrokan dunia Timur (Islam) dengan dunia Barat. Inilah yang menimbulkan kesadaran nasional dan menyeluruh dalam bentuk modern. Sebab dalam masyarakat statis kesadaran itu tak pernah dapat tumbuh dengan baik, seperti halnya dunia Islam yang tidur dengan nyenyak selama beberapa waktu yang panjang, hidup dalam kebodohan, kejumudan dan terbelakang.
Al-Afghani telah menyatakan seluruh sikap dan buah pikirannya serta berjuang atas segala jerih payahnya untuk mempersatukan negara-negara Islam dalam satu panji kekhalifahan, hanya saja Tuhan masih belum mengabulkan usahanya ini. Namun cita-cita al-Afghani ini selalu mendapat tempat yang subur di kalangan murid-murid dan pengagumnya sepanjang masa. Bila dilihat dari sifat perjuangannya, akan jelas kepada kita bahwa jalan yang ditempuhnya untuk merealisasikan cita-citanya adalah dengan jalan pemberontakan politik. Menurutnya, itulah jalan yang lebih cepat dan tepat untuk merebut dan mewujudkan kemerdekaan bagi Islam. Sudah tentu dengan kemerdekaan umat Islam, mereka akan bisa mengatur rumah tangganya sendiri, ekonomi, pendidikan, sosial politik bahkan agama yang akan diterapkan dalam kehidupannya. Sedangkan cara yang ditempuh dengan perlahan-lahan, menurutnya, terlalu panjang dan tidak dapat diyakini benar. Ia ingin melihat buah perjuangannya di masa hidupnya. ${ }^{9}$

Berdasarkan pendapat serta cara yang ditempuhnya inilah di era belakangan muncul perbedaan visi dan program kerja yang ditempuh oleh Jamaluddin al-Afghani dengan muridnya Muhammad Abduh. Ia dengan kejeniusannya selalu menginginkan ide perjuangan dengan membebaskan umat

${ }^{9}$ Charles Adams, Islam Dan Dunia Modern Di Mesir (Jakarta: Pustaka Pelajar, 1947), h. 32 
Islam dari kebodohan dan penindasan kaum

Barat lewat perjuangan politik. Sedang

Muhammad Abduh lebih memusatkan perhatiannya kepada bidang pendidikan. Bagi

Muhammad Aduh, pendidikan bagi umat

Islam sangat urgen dan sebagai tonggak lahirnya keyakinan dan kekuatan serta kedisiplinan, yang selanjutnya kuat terhadap serangan dari luar.

Dari seluruh perjalanan dan kunjungan Al-Afghani ke berbagai negara, dengan kecerdasan yang ia punya, ia banyak mendapatkan informasi lewat berbagai bacaan buku-buku asing. Lewat karya-karya yang dibacanya, justru hal itu pulalah yang membuatnya semakin cemerlang untuk menentang kezaliman di dunia muslim. Seorang muridnya, yang bernama Muhammad Syami Pusha, meminta kepadanya untuk memberi judul kumpulan perkuliahannya, dan ia berkata samhat khathirat. $^{10} \quad$ Lothrop $\quad$ Stoddard mengemukakan kesimpulan ajaran-ajaran alAfghani di sekitar politik dalam bukunya The New World of Islam yang dikutip Ahmad Amin sebagai berikut:

-Bahwa Barat menyatakan perang terhadap dunia umat Islam.

-Semangat perang salib masih membara dalam dada mereka seperti halnya dendam kesumat pertapa petrus.

${ }^{10}$ Ahmad Amin, Zuama'ul Ishlah Fil Ashril Hadits (Kairo: Lajnah Atta'lif wat Tarjamah wan Nasyr, 1947), h. 117.
-Dunia Barat senantiasa merintangi setiap usaha yang dilakukan oleh kaum muslimin untuk perbaikan dan kebangkitan di negerinegeri Islam.

-Oleh karena inilah maka seluruh dunia Islam harus bersatu padu untuk mempertahankan diri dari keruntuhan. Demi untuk mencapai tujuan itu harus dimiliki teknik kemajuan Barat dan mempelajari sebab-sebab kemajuan dan kekuasaannya. ${ }^{11}$

Jamaluddin al-Afghani menyalurkan ide-idenya lewar jalur propoganda atau media masa yang dipimpinnya maupun yang dipimpin oleh para muridnya. Cara seperti ini merupakan cara yang efektif dalam memengaruhi orang lain. Di mana saja tulisannya ditemukan hampir semua orang yang membacanya merasa tertekun dan penuh perhatian. Ini juga sangat menarik dikarenakan popularitas yang memang sudah dimilikinya, bahkan ini khususnya dirasakan oleh para kaum muda, pemimpin yang moderat bahkan kaum ekstrimis. ${ }^{12}$ Di antara mass media yang banyak memuat tulisan Jamaluddin al-Afghani antara lain, al-Mishr di bawah asuhan muridnya Adi Ishak, yang kemudian surat kabar ini menjadi surat kabar bernama Attijara.

Kemudian surat kabar Mirdat yang dipimpin langsung olehnya. Ketika tinggal di Paris, ia juga sempat menerbitkan majalah

\footnotetext{
${ }^{11}$ Ibid., h. 106.

12 Mu'ammar Syahid, "Peranan Jamaluddin
} Al-Afghani Dalam Politik," Al Jami 'ah, 1981, h. 35 
mingguan yang begitu berpengaruh dan Iran, bahkan masa tuanya ia memperdalam banyak diminati pembaca yaitu Urwatul bahasa Perancis.

Wusqa. Dalam bahasa Perancis majalah itu bernama Le lien indissiluble yang artinya tali yang kokoh. Adapun karya dalam bentuk buku antara lain tentang bantahannya terhadap kaum Dahriyyin (materialis) yaitu berjudul al Ra'du 'ala al-Dahriyyin yang sudah diterjemahkan ke dalam berbagai bahasa, di samping banyak juga tulisannya mengenai filsafat dan agama (teologi).

Goldziher mengulas kekaguman EG. Brown yang mengatakan: al-Afghani pada satu saat yang bersamaan dapat merupakan seorang filosof, penulis, orator, wartawan, bahkan oleh pencinta beliau menyebutnya sebagai nasionalis yang besar, sekaligus dipandang sebagai musuh yang sangat berbahaya bagi lawan-lawannya. ${ }^{13}$

\section{Awal Pergerakan Politik Jamaluddin Al-} Afghani

Ia memulai karir politiknya setelah kembali dari melaksanakan ibadah haji pada tahun 1851, yaitu di Afganistan sewaktu menjabat sebagai pegawai Amir yang memerintah saat itu, yakni Dust Muhammad Khan. Ia mengambil peranan penting sewaktu terjadi perang saudara yang berkepanjangan selama pemerintahan itu. Kemudian sewaktu Muhammad Azam menjabat sebagai Amir, al-Afghani diangkat sebagai Perdana Menteri pada usia 27 tahun. Perjalanan hidup yang penuh dedikasi, sebagai aktifis, matang dalam berpikir Pernyataan ini memang dapat ditopang oleh menjadikan al-Afghani kuat dalam keluasan ilmu dan pengalaman yang maupun dari dalam sebagaimana lazimnya dimilikinya sejak masa mudanya. Charles C. juga dialami oleh orang-orang besar lainnya. Adams menulis: waktu umur 18 tahun Pemerintah Inggris yang selalu merasa hampir seluruh ilmu keislaman dipelajarinya, dihantui oleh konfrontasi kritikan-kritikan ia belajar bahasa Arab, filsafat, fisika, yang penuh rasional dari al-Afghani, selalu metafisika, ilmu hitung, astronomi, obat- berusaha membuat fitnah dan berbagai obatan, anatomi, dan sebagainya. ${ }^{14}$ Demikian hasutan agar rakyat jangan sampai pula berbagai bahasa yang dikuasainya menghiraukan kecamannya terhadap Inggris. seperti, bahasa Inggris, Afganistan, Turki, Dalam misinya, al-Afghani telah dapat mengunjungi Paris, India, Hijaz, Konstantinopel, Rusia. Mesir, London dan

13 Mu'ammar Syahid, "Peranan Jamaluddin Al-Afghani Dalam Politik,” Al Jami'ah, 1981, h. 106.

${ }^{14}$ Adams, Islam Dan Dunia Modern Di Me Charles Adams, Islam Dan Dunia Modern Di Mesir (Jakarta: Pustaka Pelajar, 1947), h. 6. berbagai negara asing lainnya, kemudian menetap untuk beberapa saat sambil menyampaikan ide-ide segarnya. Di antara 
perjalanan pentingnya ialah ketika berada di Mesir pada tahun 1871 sampai 1879, di mana di negeri ini ia sendiri bisa menghasilkan kader-kader untuk meneruskan perjuangannya di masa kemudian.

Dari hasil perjalanannya yang cukup luas cakupannya tersebut membuat wawasannya juga semakin bertambah, sehingga mampu memberikan jawaban atau alternatif dari setiap permasalahan umat Islam yang ia temui. Menurut pandangan alAfghani, dunia Islam mengalami hambatan yang membuat umat Islam tidak bisa maju seperti bangsa-bangsa lain. Beberapa penyebabnya yaitu absolutisme dan despotisme penguasa muslim, dan keterbelakangan umat Islam dalam hal peradaban dan sains, serta pemikiranpemikiran yang korup. ${ }^{15}$

Di Mesir, kuliah dan diskusi yang ia lakukan tidak selamanya pada tempat-tempat khusus, tapi di manapun ia berada tetap dikelilingi oleh murid-muridnya dan para sahabatnya yang berasal dari berbagai kalangan, kaum muda dan tua. Di antara muridnya yang cukup terkenal adala Mahmud Sami al Barudi, Abdoussalam al Muwilahi dan saudaranya Ibrahin alMuwilahi. Sedang dari kaum muda adalah Muhammad Abduh, Ibrahim al-Caqoni, Sa'at
Zaglul, Ali Mudhir, Salim Naqosyi, Adib Ishak dan lain-lain. ${ }^{16}$

Ketika ia sedang berada di Mesir, kondisi keuangan negara sangat memprihatinkan, sehingga negara Barat mendapatkan kesempatan untuk ikut terlibat di dalamnya. Ia mendukung Muhammad Abduh dalam melaksanakan maksudnya untuk menyingkirkan Khedive Ismail Pasha yang telah menempuh jalan keliru dengan banyak menghamburkan uang negara dengan alasan untuk kepentingan negara. Usaha itu dapat berlangsung dengan lancar pada 25 Juni tahun 1879. Khedive Ismail sendiri terpaksa digantikan oleh anaknya Khedive Taufiq Pasha. Dalam peristiwa ini, hubungan antara Jamaluddin dengan Khedive Taufiq Pasha terjalin dengan baik, bahkan Taufiq berjanji akan menyokong cita-cita al-Afghani bila ia telah naik singgasana.

Akan tetapi setelah Taufiq dinobatkan sebagai pimpinan dia sendiri mengingkari janjinya atas hasutan pemerintah Inggris, bahkan Kabinet Dewan Menteri segera memerintahkan untuk mengusir al-Afghani yang terjadi pada 6 Ramadan 1296 H/24 Agustus 1871 dengan tuduhan bahwa alAfghani mengepalai satu organisasi pemuda yang bertujuan merusak agama dan dunia. ${ }^{17}$ Kemudian ia segera berangkat ke Mesir

${ }^{16}$ Ahmad Amin, Zuama'ul Ishlah Fil Ashril Hadits (Kairo: Lajnah Atta'lif wat Tarjamah wan Nasyr, 1947), h. 75.

17 Ahmad Amin, Zuama'ul Ishlah Fil Ashril Hadits (Kairo: Lajnah Atta'lif wat Tarjamah wan Nasyr, 1947), h. 78. 
beserta pembantunya Abu Turab, mereka mengalami kemunduran. Menurut Ahmad pergi ke India dengan pengawalan ketat Amin ada enam poin pokok yang ditulis pemerintah Inggris. Ia pertama kalinya yaitu:

diasingkan di Heydrabat kemudian di 1. Keterangan tentang kewajiban yang harus Kalkutta di mana Inggris memaksanya untuk dilaksanakan oleh bangsa-bangsa Timur yang tinggal di sana selama perang Urabi Pasha. sedang berada dalam situasi dan kondisi Selama dalam pengasingan itu ia menulis sebuah karangan yang mengritik tajam ajaran Darwin dalam bahasa Persi. Ia mengatakan bahwa hanya agamalah yang bisa memulihkan kestabilan masyarakat dan pertahanan nasional. Setelah Urabi runtuh ia meninggalkan India dan langsung menuju Paris, dan di sini ia secara aktif melakukan proganda atas kebijakan Inggris terhadap negara-negara Islam lewat surat kabar Perancis.

$$
\text { Pada tahun } 1884 \text { al-Afghani }
$$
sangat rendah dan lemah, serta menjelaskan bagaimana jalan yang harus ditempuh untuk mengejar ketertinggalan dunia Islam, dan yang menyebabkan rusaknya dunia Timur pada umumnya.

2. Menyegarkan jiwa dengan keyakinan bahwa semua cita-cita pasti tercapai bila dibarengi dengan usaha yang serius dan hilangakan ras pesimis.

3. Menolak segala apa yang dilontarkan terhadap dunia Timur atas berbagai tuduhan, mengadakan kerjasama dengan para khususnya kaum muslimin, dan membantah muridnya untuk menerbitkan majalah mingguan dalam bahasa Arab yang namanya Urwatul Wusqa. Majalah itu secara gratis dikirimkan kepada berbagai organisasi dan siapa saja yang membutuhkan. Hanya saja banyak yang tidak sampai ke alamat tujuan karena disita oleh pejabat pemerintah Inggris, semua pendapat bahwa kaum muslimin tidak mau mengembangkan peradaban dan selamanya terbelakang selama mereka berpegang kepada agamanya.

4. Seruan untuk berpegang kepada asal-usul kebangsaan dari mana nenek moyang mereka, seperti yang sudah dibuktikan kerajaan-kerajaan asing.

termasuk yang semestinya dikirim ke 5. Memberikan informasi perkembangan wilayah Mesir misalnya. Kendati usia politik internasional dan politik nasional penerbitan majalah ini relatif pendek, tapi kepada semua dunia Timur, dan ini perlu pengaruhnya cukup besar hampir ke seluruh untuk diketahui.

dunia Islam. Ini disebabkan karena isi dari 6. Menggiatkan salat di kalangan umat Islam, mass media tersebut berisikan doktrin- memperkokoh rasa persaudaraan, menjaga doktrin yang membangkitkan semangat kepentingan bersama, membantu politik luar kebangsaan umat Islam yang sedang 
negeri yang tidak merugikan kepentingan bangsa timur. ${ }^{18}$

Setelah pencabutan izin terbit majalah tersebut dan setelah mengunjungi London pada tahun 1885, atas anjuran Mr. Blunt, Inggris mendekatinya dan bermaksud menggabungkannya dengan gerakan Mahdi di Sudan. Tapi perasaan anti Inggrisnya menyebabkan ia menolak mentah-mentah tawaran itu.

\section{Pengaruhnya Dalam Politik}

Jamaluddin al-Afghani adalah tokoh pembaharu Islam yang gigih dan berjiwa besar lewat politik, yang disenangi oleh kawan-kawannya dan disegani oleh musuhmusuhnya, memiliki pengaruh yang sangat besar dalam dunia politik, yang secara tegas membuat sebuah garis pemisah yang tegas antara Timur dan Barat, antara penjajahan dengan masyarakat yang ingin kemerdekaan.

Pengaruh Jamaluddin dapat kita lihat dalam setiap kota dan negara yang ditempatinya, baik di Timur maupun Barat seperti: Paris, Inggris, Rusia, Konstantinopel, Madinah, India dan Iran. $^{19}$ Dia selalu disegani dan ditakuti oleh lawan politiknya karena ia tidak takut sedikitpun untuk masuk penjara seandainya tidak ada pilihan lain lagi, tidak merasa terhina oleh suatu ejekan, tidak

18 Ahmad Amin, Zuama'ul Ishlah Fil Ashril $\infty$ Hadits (Kairo: Lajnah Atta'lif wat Tarjamah wan N Nasyr, 1947), h. 81-82.

$\begin{array}{r}\text { Ahmad Hanafi, Pengantar Teologi } \\ \text { (Jakarta: Pustaka Al Husna Baru, 2003), h. } 166 . \\ \hline\end{array}$ menderita karena kemiskinan, baginya agama adalah satu hal yang sangat berharga dan mulia, karena itu harus diperjuangkan. Setiap tempat yang dilaluinya ditemukan idenyaidenya. Ia menyampaikan banyak pemikirannya lewat sebuah audensi atau secara individu, semangatnya berkobar hampir dalam setiap hati muridnya. Bahkan suatu saat seorang muridnya bercita-cita untuk membunuh pangeran Shah di Iran karena menghalang-halangi al-Afghani untuk berjuang melawan penjajah.

Manuver politik dan Gerakan yang dilakukan oleh al-Afghani meluas dari satu negara ke negara lain. Pada tahun 1884, ketika berada di Paris, al-Afghani bekerja sama dengan muridnya yang bernama Muhammad Abduh untuk mendirikan Gerakan masyarakat yang disebut Jamiyat alUrwa al-Wuthqa (Society of Indissouble Bond). Tujuan dari gerakan tersebut adalah untuk mempersatukan masyarakat Islam yang terpecah belah, dan berusaha untuk memberikan solusi atas perpecahan tersebut, dan membangkitkan mereka dari tidur lelapnya. Oleh sebab itu al-Afghani mendirikan surat kabar mingguan berbahasa Arab bernama "al-Urwa al-Wuthqa". Melalui media tersebut, ada dua sasaran pokok yang hendak dicapainya. Pertama, menggerakkan aksi-aksi perjuangan rakyat untuk membebaskan Mesir dari pengaruh Inggris. Kedua, membangkitkan dan menumbuhkan 
kesadaran di kalangan bangsa-bangsa Timur akan bahaya penjajahan dan dominasi Eropa.

Pengaruh politik al-Afghani yang sangat besar memang dihasilkan lewat surat kabar dan majalah baik yang dipimpin langsung olehnya maupun oleh muridmuridnya, terutama isu-isu besarnya adalah masalah tirani penjajahan. Hal ini nampak pada majalah Urwatul Wusqa, seperti yang disebutkan sebelumya. Penyampaiannya bersifat dinamis, keras, tajam serta revolusioner. Lebih tegas lagi ketika alAfghani sempat bertemu dan mengadakan perbincangan dengan anggota Parlemen Inggris dan dengan Lord Harlington Menteri Peperangan Inggris yang hidup tahun 18331908. Dia dianggap sebagai tokoh revolusi Mesir dan beliau mengatakan dengan tegas keinginan rakyat Mesir, yaitu agar tentara Inggris meninggalkan negeri Mesir, keinginan tersebut juga dikemukakannya kepada wakil-wakil surat kabar di Inggris antar lain: Times, Truth dan Pan Mall Gazette. $^{20}$

\section{Al-Afghani selalu menyampaikan} dakwah kepada masyarakat muslim khususnya orang-orang Mesir bahwa Inggris merupakan pelanggar hak-hak asasi manusia dengan seringnya memperbudak manusia. Ia selalu mengobarkan semangat untuk melawan penjajah dari negeri mereka, dan tidak perlu mengakui kekuasaan asing,

20 Mu'ammar Syahid, "Peranan Jamaluddin Al-Afghani Dalam Politik," Al Jami'ah, 198, h. 41. Jurnallntelektual: Jurnal Pendidikan dan Studi Keislaman Volume 10, Nomor 2, Agustus 2020 bahkan para penjajah tersebut harus dilawan dan dimusnahkan meskipun dengan senjata. ${ }^{21}$

Ketika Inggris masuk dan mulai mencampuri urusan politik yang ada di Mesir. Al-Afghani kemudian bergabung dengan salah satu organisasi bernama "Free Masons" dengan tujuan menentang campur tangan Inggris dalam urusan politik Mesir. Setelah bergabung dengan organisasi tersebut, al-Afghani kemudian mendirikan partai nasional (Hizbul Wathan) pada tahun 1879M, yang mana partai tersebut mempunyai semboyan "Mesir untuk orang Mesir".22

Meskipun pada akhirnya al-Afghani harus diusir dari Mesir. Akan tetapi ide-ide pembaharuan dan aktifitas politik yang ia kembangkan selama ini telah membekas dan berpengaruh secara dalam pada diri tokoh reformis Mesir. Karena pengaruhnya yang besar tersebut ia kemudian digelari sebagai bapak Nasionalisme Mesir.

Selain di Mesir, pengaruh Jamaluddin juga terlihat di beberapa negara seperti India dan Afghanistan. Pada waktu itu al-Afghani melakukan perjalanan dari Kabul ke India untuk mencari pendidikan modern. Ketika berada di India ia tidak suka dengan perlakuan kaum kolonialis yang selalu

21 Didin Saefuddin, Pemikiran Modern Dan Postmodern Islam: Biografi Intelektual 17 Tokoh (Jakarta: Gramedia Widiasarana Indonesia, 2003), h. 24.

22 Akmal hawi, "Pemikiran Jamaluddin AlAfghani (1838 - 1897 M)," Medina Vol. 16 (June 2017), h. 22. 
menindas rakyat. Dari sinilah kemudia ia yang didukung oleh rakyat sajalah yang memulai kiprah awalnya sebagai aktifis mampu menjadi stabil, kuat, dan merupakan politik yang berbakat. Hal tersebut terbukti senjata untuk melawan dominasi asing. Apa dengan kepiawaiannya sebagai orator yang yang dilakukan al-Afghani kemudian mampu membakar semangat rakyat India, memberikan dampak dan kontribusi yang sehingga rakyat India terdorong untuk melatarbelakangi munculnya pemberontakan melawan kekuasaan Inggris. Hasilnya pada Arabi Pasha di Mesir dan gerakan tahun 1857 rakyat India bangkit melawan konstitusional di Persia, dan dampak penjajah hingga perang kemerdekaan di seruannya secara umum dirasakan juga di Indiapun muncul untuk pertama kalinya. ${ }^{23}$

Setelah dari India al-Afghani bertolak Turki dan India. Usaha yang dilakukan alAfghani untuk menggerakkan kekuatan ke Afghanistan karena diminta oleh penguasa rakyat tidak hanya membangkitkan sentimenAfghanistan bernama pangeran Dost sentimen dalam lingkup universal, akan Muhammad untuk membantunya dalam pemerintahan. Bukan tanpa alasan mengapa tetapi sentimen-sentimen dalam lingkup nasional atau lokal pun ia lakukan di pangeran tersebut memilih al-Afghani berbagai negara. Oleh sebab itu pengaruh alsebagai pembantunya dalam pemerintahan. Afghani sesungguhnya tertuju kepada PanIde-ide dan pergerakan cemerlang yang Islamisme maupun nasionalisme. dimiliki oleh al-Afghani menjadi salah satu faktor utama pangeran tersebut memilihnya.

\section{Kesimpulan}

Menurut Fazlur Rahman ${ }^{24}$, terdapat

Di bagian akhir tulisan ini dapat dua elemen yang menonjol dalam pemikiran dibuat sebuah ringkasan:

politik Jamaluddin al-Afghani: persatuan 1. Jamaluddin al-Afghani reformer pertama Islam sedunia dan populisme. Doktrin dalam Islam yang membawakan faham persatuan Islam sedunia tampak jelas salafiyah di bawah naungan panji Pan terpampang pada istilah yang dikenal dengan Islamisme, dengan prinsip bahwa umat Islam Pan-Islamisme. Dorongan populisme muncul di manapun ia berada adalah merupakan The karena pertimbangan keadilan intrinsiknya maupun langsung dari kenyataan bahwa Unity of Brotherhood atau satu kesatuan hanya sistem pemerintahan konstitusional persaudaraan yang harus dibina terus.

2. Ia adalah seorang perintis yang meletakkan rukun iman harus dijadikan sebagai landasan pokok untuk bersatu, dan menyerukan agar Jamaluddin Al-Afghani Dalam Pemikiran Modern Islam," Tajdid 22 (2019): 90. 
3. Jamaluddin al-Afghani mengatakan bahwa, satu-satunya yang paling revolusioner untuk membebaskan nasib umat Islam dari kolonialisme, imperlialisme dan materialisme hanyalah dengan politik yang dijiwai dengan agama, seperti revolusi Iran yang dimotori oleh seorang ulama tua yang banyak mengetahui soal-soal agama dan politik terutama setelah pengasingannya di Perancis, itulah Ayatullah Rahullah Khomeini.

4. Jamaluddin al-Afghani sebagai reformer Islam berusaha keras memperbaiki Islam dari dalam dengan menyerang habis-habisan faham takhayul, khurafat dan bid'ah.

5. Ia adalah seorang yang tekun dalam perjuangan untuk mengembalikan semangat umat Islam, terutama usahanya untuk menghilangkan rasa rendah diri dan pesimisme yang selama ini melanda umat Islam.

6. Membantah semua tuduhan yang mengatakan umat Islam anti kemajuan, dan umat Islam akan selamanya mundur jikalau berpegang kepada ajaran Islam.

\section{Daftar Pustaka}

Adams, Charles. Islam Dan Dunia Modern Di Mesir. Jakarta: Pustaka Pelajar, 1947.

Amin, Ahmad. Zuama'ul Ishlah Fil Ashril Hadits. Kairo: Lajnah Atta'lif wat Tarjamah wan Nasyr, 1947.

Aziz, Abdul. CHIEFDOM MADINAH, Salah Paham Negara Islam. Jakarta: Pustaka Alvabet, 2011.
Gibb, HAR. Muhammedenism, Terj. Abu Salama. Islam Dalam Lintasan Sejarah. Jakarta: Bhrata, 1961.

Gibb, HAR, and J.H Kramers. Shorter Encyclipedia of Islam. Nederland: Shorter Encyclipedia of Islam, 1961.

Hanafi, Ahmad. Pengantar Teologi Islam. Jakarta: Pustaka Al Husna Baru, 2003.

hawi, Akmal. "Pemikiran Jamaluddin AlAfghani (1838 - 1897 M)." Medina Vol. 16 (June 2017).

Hazem, Zaki. The Ideas of Arab Nationalism, Terj. Mertodipuro Gagasan Nasionalisme Arab. Jakarta: Bhrta, 1969.

Iqbal, Muhammad. Pemikiran Politik Islam: Dari Masa Klasik Hingga Indonesia Kontemporer. Jakarta, 2010.

Ismail, Faisal. Studi Islam Kontemporer. Yogyakarta: IRCiSoD, 2018.

M. Romli, Asep Syamsul. Demonologi Islam: Upaya Barat Membasmi Kekuatan Islam. Jakarta: Gema Insani, 2000.

Noorthaibah. "Pemikiran Pembaharuan Jamaluddin Alafghani: Studi Pemikiran Kalam Tentang Takdir." Fenomena Vol. 7 (2015).

Rahman, Fazlur. Islam. Chicago: The University of Chicago Press, 1979.

Saefuddin, Didin. Pemikiran Modern Dan Postmodern Islam: Biografi Intelektual 7 Tokoh. Jakarta: Gramedia Widiasarana Indonesia, 2003.

Sukmanila, Dwi. "Kiprah Dan Kontribusi Jamaluddin Al-Afghani Dalam Pemikiran Modern Islam." Tajdid 22 (2019): 90. 
Syahid, Mu'ammar. 'Peranan Jamaluddin

Al-Afghani Dalam Politik." $A l$

Jami'ah, 1981. 